\title{
Sensitisation of cariogenic bacteria to killing by light from a helium-neon laser
}

\author{
T. BURNS, M. WILSON and G. J. PEARSON* \\ Departments of Microbiology and "Biomaterials, Institute of Dental Surgery, 256 Grays Inn Road, \\ London WC1X 8LD
}

\begin{abstract}
Summary. Suspensions of the cariogenic bacteria Streptococcus mutans, S. sobrinus, Lactobacillus casei and Actinomyces viscosus were exposed to light from a 7-3-mW heliumneon laser in the presence of toluidine blue $O$. A substantial killing rate $\left(c .10^{6} \mathrm{cfu}\right)$ of all four species was achieved with a dye concentration of $50 \mu \mathrm{g} / \mathrm{ml}$ and a light energy dose of $33.6 \mathrm{~J} / \mathrm{cm}^{2}$. This was achieved in $60 \mathrm{~s}$, an exposure time that is clinically acceptable. Exposure to laser light in the absence of the dye did not significantly affect the viability of any of the organisms. This approach may be useful in dentistry to sterilise a carious lesion prior to its repair.
\end{abstract}

\section{Introduction}

Dental caries is a chronic invasive disease which involves initial demineralisation of the tooth followed by destruction of the organic phase of the dentine. The organisms reported to be responsible include Streptococcus mutans, S. sobrinus, Lactobacillus casei and Actinomyces viscosus. ${ }^{1}$ Current methods of treating the resulting dentinal lesion involve the mechanical removal of sound tooth tissue, to gain access to the carious lesion, as well as the removal of softened and infected dentine. The methods of removal are relatively unsophisticated and there is no objective method to assess whether sufficient infected tissue has been removed to prevent re-infection. It would be advantageous, therefore, if bacteria could be killed in situ, reducing the amount of tissue needing to be removed. This could be achieved by the use of lethal photosensitisation, which involves treating target organisms with photosensitising agents, e.g., various dyes, thus rendering them susceptible to killing by light from low-power lasers. ${ }^{2-4}$ Recently, it has been shown that several species of oral bacteria, including a major plaque-forming organism, $S$. sanguis, can be killed in this way. ${ }^{5-8}$ The purpose of this investigation was to determine whether cariogenic bacteria could be killed by this technique with toluidine blue $O$ (TBO) as a sensitiser and a helium-neon ( $\mathrm{HeNe}$ ) laser as the light source.

\section{Materials and methods}

\section{Organisms}

S. mutans NCTC 10449, S. sobrinus NCTC 10921, L. casei NCTC 10302 and A. viscosus NCTC 109451 were used. These were maintained by subculture on blood agar (Oxoid) $5 \%$ every 7 days. Cultures grown for $16 \mathrm{~h}$ in Tryptone Soya Broth (TSB; Oxoid) at $37^{\circ} \mathrm{C}$ in an anaerobic jar were used for the experiments.

Laser

A helium-neon (HeNe) gas laser (NEC Corporation, Japan) with a power output of $7.3 \mathrm{~mW}$ at a wavelength of $632.8 \mathrm{~nm}$ was used. The beam diameter was $1.3 \mathrm{~mm}$.

Determination of minimum bactericidal concentration of dye

TBO (CI 52040) in TSB was added to 16-h cultures to give final concentrations of $0 \cdot 1-1000 \mu \mathrm{g} / \mathrm{ml}$. These were incubated for $1 \mathrm{~h}$ at $37^{\circ} \mathrm{C}$ and surviving bacteria were counted after plating samples on to tryptone soya agar (TSA) and anaerobic incubation at $37^{\circ} \mathrm{C}$ for $24 \mathrm{~h}$.

\section{Lethal photosensitisation of target organisms}

Screening assay. TBO was added to 16 -h cultures to give final concentrations of 100,50 and $25 \mu \mathrm{g} / \mathrm{ml}$. Controls received only TSB. These were incubated at room temperature for $15 \mathrm{~min}$. A $1-\mathrm{ml}$ volume was poured over a TSA plate, the excess was removed, and the plate was dried at $37^{\circ} \mathrm{C}$ for $1 \mathrm{~h}$. Different areas of the plate were then exposed in duplicate to laser light for periods of 15-300 s. After anaerobic incubation for 
$24 \mathrm{~h}$ at $37^{\circ} \mathrm{C}$, the plates were examined for growth-free zones, then re-incubated for $48 \mathrm{~h}$ and examined for growth within these zones.

Quantitative assay. Equal volumes $(100 \mu \mathrm{l})$ of each bacterial suspension and various concentrations of TBO in TSB were mixed in wells of a microtitration plate (Sterilin Ltd, Hounslow); controls received only TSB. Magnetic stirrer bars $(4 \mathrm{~mm})$ were added to the wells, the plate was placed on a magnetic stirrer and the suspensions were exposed to light from the $\mathrm{HeNe}$ laser. To determine the effect of the dye alone, the wells were prepared with the hacterial suspension in the presence of the dye but not exposed to the laser light. Additional control wells contained the bacterial suspension to which TSB had been added without the dye and these were not exposed to the laser. Survivors were enumerated by viable counting on TSA plates.

\section{Results}

\section{Minimum bactericidal concentrations of dye in the absence of laser light}

TBO caused a dose-related decrease in the viability of the target organisms in the absence of laser light (fig. 1a-d). Of the four organisms tested, S. sobrinus and $L$. case $i$ were the most sensitive to TBO. On exposure to
$1 \mu \mathrm{g} / \mathrm{ml}$ of the dye for $1 \mathrm{~h}$ there was a statistically significant decrease in their viability (Student's $t$ test, $\mathrm{p}<0.05)$. $S$. mutans and $A$. viscosus were more resistant, and a TBO concentration of $100 \mu \mathrm{g} / \mathrm{ml}$ was required to produce a similar decrease in viability (fig. la-d).

\section{Lethal photosensitisation}

Screening assay. S. mutans, S. sobrinus and $A$. viscosus were killed after a minimum exposure time of $15 \mathrm{~s}$ (energy density $=8.4 \mathrm{~J} / \mathrm{cm}^{2}$ ) with a dye concentration of $100 \mu \mathrm{g} / \mathrm{ml}$ (table). However, when the same concentration of dye was used, $L$. case $i$ was killed only after exposure to the laser light for at least $45 \mathrm{~s}$ (energy density $=25 \cdot 2 \mathrm{~J} / \mathrm{cm}^{2}$ ). At a TBO concentration of $50 \mu \mathrm{g} / \mathrm{ml}, L$. casei again appeared to be less sensitive to the laser light in that it was killed only after an exposure time of at least $45 \mathrm{~s}$, although killing was observed with $S$. mutans, $S$. sobrinus and $A$. viscosus after exposure for $30 \mathrm{~s}$ (energy density $=16.8 \mathrm{~J} / \mathrm{cm}^{2}$ ). When sensitised by TBO $25 \mu \mathrm{g} / \mathrm{ml}, S$. mutans required an exposure time of only $30 \mathrm{~s}$ for a bactericidal effect to be detectable whereas the other organisms required $60 \mathrm{~s}$ (energy density $=33.6 \mathrm{~J} / \mathrm{cm}^{2}$ ), indicating that $S$. mutans was more sensitive to the laser light (table). Neither the dye nor the laser alone had any de-

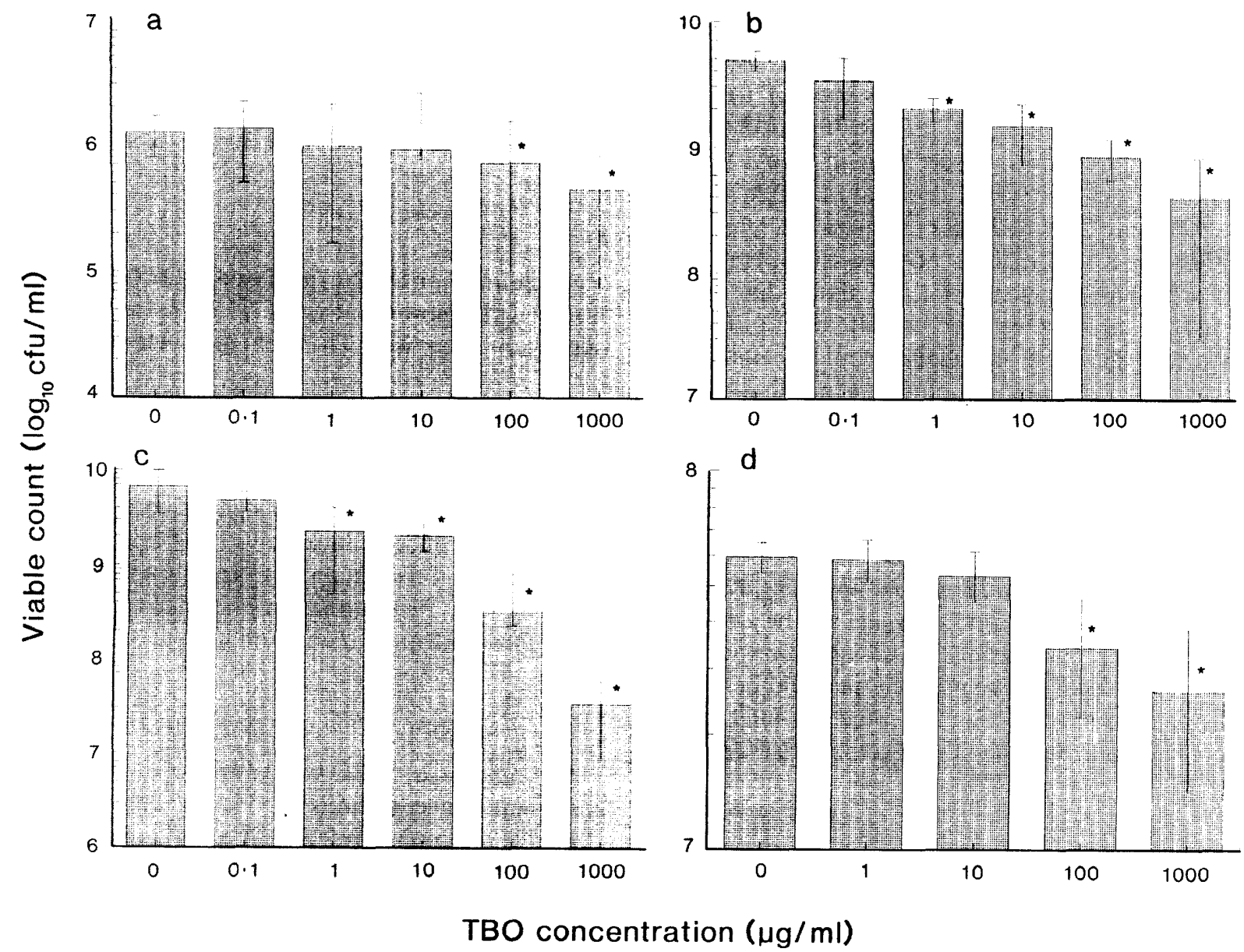

Fig. 1. Effect of TBO on the viability of a, S. mutans; b, S. sobrinus; c, L. casei; d, A. viscosus. Error bars represent $95 \%$ confidence intervals (CI). *The viable count was significantly different from that of the dye-free control (Student's $t$ test, $p<0 \cdot 005$ ). 
Table. Screening for lethal photosensitisation of target bacteria on the surfaces of agar plates when sensitised by TBO and exposed to light from a 7·3-mW HeNe laser

\begin{tabular}{|c|c|c|c|c|c|c|c|c|c|}
\hline \multirow{2}{*}{ Organism } & \multirow{2}{*}{$\begin{array}{c}\text { TBO } \\
\text { concentration } \\
(\mu \mathrm{g} / \mathrm{ml})\end{array}$} & \multicolumn{8}{|c|}{ Killing after exposure time (s) of } \\
\hline & & 15 & 30 & 45 & 60 & 120 & 180 & 240 & 300 \\
\hline S. mutans & & + & + & + & + & + & + & + & + \\
\hline S. sobrinus & 100 & + & + & + & + & + & + & + & + \\
\hline L. casei & & - & - & + & + & + & + & + & + \\
\hline A. viscosus & & + & + & + & + & + & + & + & + \\
\hline S. mutans & & - & + & + & + & + & + & + & + \\
\hline S. sobrinus & 50 & - & + & + & + & + & + & + & + \\
\hline L. casei & & - & - & + & + & + & + & + & + \\
\hline A. viscosus & & - & + & + & + & + & + & + & + \\
\hline S. mutans & & - & + & + & + & + & + & + & + \\
\hline S. sobrinus & 25 & - & - & - & + & + & + & + & + \\
\hline L. casei & & - & - & - & + & + & + & + & + \\
\hline A. viscosus & & - & - & - & + & + & + & + & + \\
\hline
\end{tabular}

+ , Presence of a growth-free zone.

-, Absence of a growth-free zone.
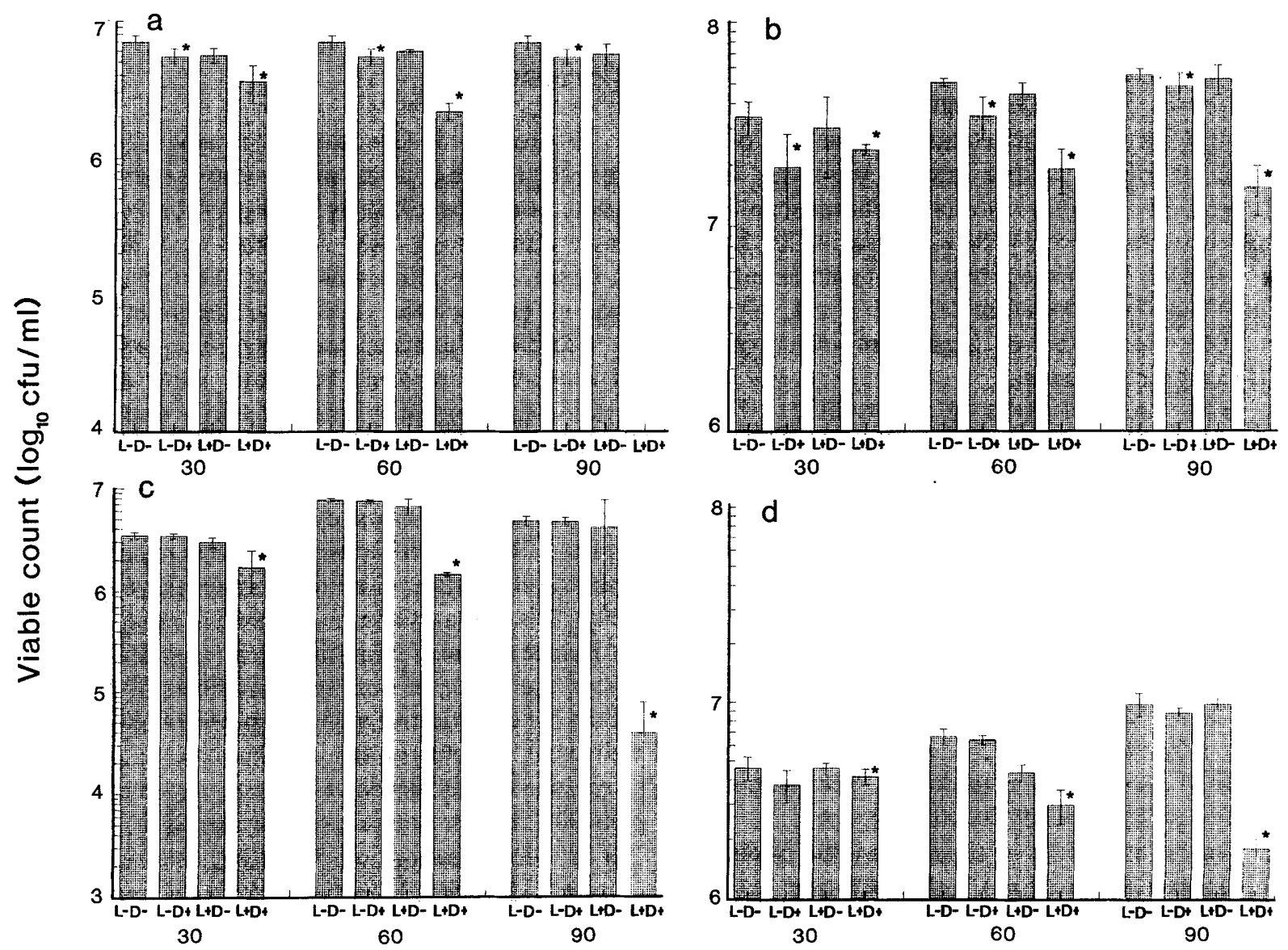

Exposure time (s)

Fig. 2. Effect of laser light on the viability of bacterial suspensions in the presence of TBO $50 \mu \mathrm{g} / \mathrm{ml}: \mathbf{a}, S$. mutans; $\mathbf{b}, S$. sobrinus; c, L. casei; d, A. viscosus. $\mathrm{L}-\mathrm{D}-$ : exposure to neither laser light nor dye (control); $\mathrm{L}-\mathrm{D}+$, exposure to the dye but not the laser light; $\mathrm{L}+\mathrm{D}-$ exposure to laser light but not the dye; L+D , exposure to both the laser light and dye. Error bars represent $95 \% \mathrm{CI}$. ${ }^{*} \mathrm{The}$ viable count was significantly different from that of the control $(L-D-)$.

monstrable effect on the organisms because there was growth in the presence of the dye on areas of the plate not exposed to laser light, and on control plates exposed to laser light in the absence of the dye.

Quantitative assays. Exposure of the four target bacteria to the $\mathrm{HeNe}$ light for varying times following sensitisation with TBO $50 \mu \mathrm{g} / \mathrm{ml}$ caused an energy dose-related decrease in their viability (fig. 2a-d). Exposure for $30 \mathrm{~s}, 60 \mathrm{~s}$ and $90 \mathrm{~s}$ resulted in substantial reductions in the viable count of $S$. mutans of $3.37 \times$ 


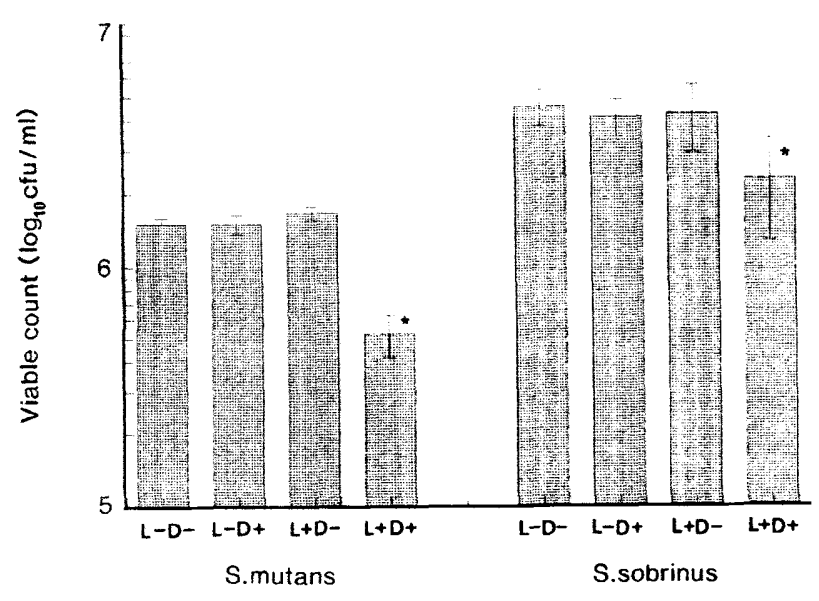

Fig. 3. Effect of laser light on the viability of $S$. mutans and $S$. sobrinus suspensions in the presence of TBO $25 \mu \mathrm{g} / \mathrm{ml}$. Error bars represent $95 \% \mathrm{CI} .{ }^{*}$ The viable count was significantly different from that of the control $(\mathrm{L}-\mathrm{D}-)$

$10^{6} \mathrm{cfu}(49 \%$ of original count $), 4.8 \times 10^{6} \mathrm{cfu}(69 \%$ kill) and $6.98 \times 10^{6} \mathrm{cfu}(100 \%$ kill $)$, respectively. However, the dye alone caused a statistically significant reduction in the viable count of $S$. mutans and accounted for $23 \%, 22 \%$ and $22 \%$ of the overall bactericidal effect. Taking into account this direct toxicity, the bactericidal effects attributable to lethal photosensitisation were $1.84 \times 10^{6} \mathrm{cfu}, 3.27 \times 10^{6} \mathrm{cfu}$ and $5.45 \times 10^{6} \mathrm{cfu}$, respectively. The mean lethal dose of laser light was therefore $1.22 \times 10^{-4} \mathrm{~mJ} /$ cell. The laser light alone had no significant effect on the viability of the organism.

A substantial reduction in the viability of dyetreated $S$. sobrinus resulted from exposure to the laser light; the killing rate was $5.8 \times 10^{6} \mathrm{cfu}(17 \%), 1.54 \times$ $10^{7} \mathrm{cfu}(30 \%)$ and $3.32 \times 10^{7} \mathrm{cfu}(62 \%)$, following exposure times of 30,60 and $90 \mathrm{~s}$, respectively. However, a statistically significant effect was also observed with the dye alone and accounted for reductions of $4.8 \times 10^{6} \mathrm{cfu}(14 \%), 1.61 \times 10^{7} \mathrm{cfu}(31 \%)$ and $6.8 \times 10^{6} \mathrm{cfu}(12 \%)$, respectively. Therefore, kills due to lethal photosensitisation amounted to $5.8 \times$ $10^{6} \mathrm{cfu}, 1.54 \times 10^{7} \mathrm{cfu}$ and $3.32 \times 10^{7} \mathrm{cfu}$ for exposure times of 30,60 and $90 \mathrm{~s}$, respectively. The mean lethal dose of laser light was $2.87 \times 10^{-5} \mathrm{~mJ} /$ cell.

In view of the toxicity of the dye to these organisms in the absence of laser light, lethal photosensitisation was attempted with a lower concentration of TBO. With a TBO concentration of $25 \mu \mathrm{g} / \mathrm{ml}$ followed by exposure to HeNe light for $60 \mathrm{~s}$, a substantial reduction in the numbers of viable bacteria was achieved (fig. 3 ). For $S$. mutans this amounted to a kill of $1.03 \times 10^{6} \mathrm{cfu}$ $(66 \%)$, of which $99 \%$ was attributable to lethal photosensitisation; the mean lethal dose of laser light was $4.3 \times 10^{-4} \mathrm{~mJ} /$ cell. A similar reduction in the viability of $S$. sobrinus was observed with a kill of $1.81 \times 10^{6} \mathrm{cfu}$ attributable to lethal photosensitisation; the mean lethal dose of laser light was $2.42 \times$ $10^{-3} \mathrm{~mJ} /$ cell. In both cases, the decrease in the viability of the organism was statistically significant $(p=0.003$ for both organisms). Neither the dye nor the laser light alone caused a significant decrease in the viability of either streptococcal strain.

Dye-sensitised $L$. case $i$ also exhibited a dose-related decrease in viability on exposure to the $\mathrm{HeNe}$ light with reductions of $2.26 \times 10^{6} \mathrm{cfu}(65 \%), 6.2 \times 10^{6} \mathrm{cfu}$ $(81 \%)$ and $4.84 \times 10^{6} \mathrm{cfu}(99 \%)$, following exposure for $30 \mathrm{~s}, 60 \mathrm{~s}$ and $90 \mathrm{~s}$, respectively. Neither the dye nor the laser light alone had a statistically significant effect on the viability of the organism. The mean lethal dose of laser light was $1.04 \times 10^{-4} \mathrm{~mJ} /$ cell.

An energy dose-related decrease in the viability of dye-sensitised $A$. viscosus was also observed. Following sensitisation with TBO $50 \mu \mathrm{g} / \mathrm{ml}$ and exposure to the HeNe laser for $30 \mathrm{~s}, 60 \mathrm{~s}$ and $90 \mathrm{~s}$, reductions of $4 \times 10^{5} \mathrm{cfu}(10 \%), 3.7 \times 10^{6} \mathrm{cfu}(56 \%)$ and $8 \times 10^{6} \mathrm{cfu}$ $(82 \%)$, respectively, were achieved. Neither the dye nor the laser light alone had an effect on the viability of the organism that was statistically significant. The mean lethal dose of laser light was $2.55 \times 10^{-4} \mathrm{~mJ} /$ cell.

\section{Discussion}

The results of this in-vitro investigation have demonstrated that four major cariogenic species of bacteria can be killed by red light from a low-power laser after having been sensitised with TBO. In the absence of the photosensitising agent, the laser light had no effect on the viability of the target organisms.

For clinical convenience, this technique should have a short laser exposure time and a low dye concentration to avoid problems of toxicity and staining of the surrounding hard tissue. In the present investigation results of the preliminary screening programme showed that the lowest dye concentration was $25 \mu \mathrm{g}$ / $\mathrm{ml}$ and the shortest exposure time $60 \mathrm{~s}$ to achieve lethal photosensitisation of all four target organisms. However, this probably does not represent a major bacterial kill since a zone of inhibition on an agar plate can arise from the killing of only small numbers of organisms.

In the quantitative assays, a substantial bactericidal effect (c. $10^{7} \mathrm{cfu}$ ) on dye-sensitised $S$. mutans and $S$. sobrinus was achieved with laser exposure times of $60-90 \mathrm{~s}$, but in both cases, the dye itself, when used at a concentration of $50 \mu \mathrm{g} / \mathrm{ml}$, exerted a major bactericidal effect. However, a lower dye concentration $(25 \mu \mathrm{g} / \mathrm{ml})$ had no significant effect on bacterial viability in the absence of laser light yet was an effective lethal photosensitiser; kills of the order of $10^{7} \mathrm{cfu}$ for both organisms were achieved following exposure to laser light for $60 \mathrm{~s}$. On the basis of lethal light dose/cell, $S$. sobrinus appeared to be more susceptible than $S$. mutans, but direct comparisons are difficult in view of unavoidable differences in the initial cell density of the irradiated suspensions.

In contrast to the streptococci, $A$. viscosus and $L$. case $i$ appeared to be more resistant to the lethal effects of TBO at a concentration of $50 \mu \mathrm{g} / \mathrm{ml}$ in the absence of laser light. In neither case was viability significantly 
decreased following exposure to this concentration of the dye for up to $90 \mathrm{~s}$. However, MBC determinations showed that the viability of $L$. casei was reduced by such concentrations following exposure for $1 \mathrm{~h}$. TBO was an effective photosensitiser of both species enabling substantial reductions in viability $\left(c .10^{6} \mathrm{cfu}\right)$ following irradiation for $60 \mathrm{~s}$; the lethal light dose/cell was similar for both species.

In a report concerning the lethal photosensitisation of a cariogenic organism, Venezio et al. ${ }^{9}$ reported that $S$. mutans could be killed by irradiation with polychromatic light after the organisms had been sensitised with a haematoporphyrin derivative. An exposure time of $20 \mathrm{~min}$ was required and no indication of the numbers of bacteria killed was given. It is known that TBO can act as a lethal photosensitiser of bacteria and Mathews ${ }^{2}$ and MacMillan et al. ${ }^{3}$ have reported the use of this dye to sensitise bacteria to killing by white light and light from $\mathrm{HeNe}$ laser, respectively. Wilson et $a l^{5,7,8}$ reported the use of TBO and other dyes to sensitise $S$. sanguis and a number of periodontal bacterial pathogens to killing by light from a $\mathrm{HeNe}$ laser. In the present investigation, the concentrations of TBO and the light energy densities needed to kill cariogenic species were similar to those found to be effective against $S$. sanguis and Porphyromonas gingivalis, Fusobacterium nucleatum and Actinobacillus actinomycetemcomitans that are pathogenic to the periodontium. The fact that TBO can sensitise cariogenic bacteria to killing by low power laser light may have clinical implications and in this regard bacteria on the cavity walls and floor could be killed after minimal cavity preparation prior to restoration of the carious lesion. Bacteria in the partially demineralised tissue may also be killed, the possible result of which may be that the amount of diseased tooth tissue requiring to be removed may be reduced. Although the results of this preliminary study are encouraging, further in-vitro studies are needed to determine whether lethal photosensitisation of cariogenic bacteria is possible under conditions more closely resembling those encountered in the carious lesion in vivo where intervening partially decalcified tissue may reduce its effectiveness.

We thank the Department of Health for funding this research.

\section{References}

1. Joyston Bechal S, Kidd EAM (eds). Essentials of Dental Caries. The disease and its management. Wright, Bristol. 1987: 1-15.

2. Mathews MM. Comparative study of lethal photosensitization of Sarcina lutea by 8-methoxypsoralen and by toluidine blue. J Bacteriol 1963; 85: 322-328.

3. MacMillan JD, Maxwell WA, Chichester CO. Lethal photosensitization of microorganisms with light from a continuous-wave gas laser. Photochem Photobiol 1966; 5: 555-565.

4. Bedwell J, Holton J, Vaira D, MacRobert AJ, Brown SG. In vitro killing of Helicobacter pylori with photodynamic therapy (letter). Lancet 1990; 335: 1287.

5. Wilson M, Dobson J, Harvey W. Sensitisation of oral bacteria to killing by low-power laser radiation. Curr Microbiol 1992; 25: 77-81.

6. Dobson J, Wilson M. Sensitisation of oral bacteria in biofilms to killing by light from a low-power laser. Arch Oral Biol 1992; 37: 883-887.

7. Wilson M, Dobson J, Harvey W. Sensitisation of Streptococcus sanguis to killing by light from a helium/neon laser. Lasers Med Sci 1992 (in press).

8. Wilson M, Dobson J, Sarkar S. Sensitisation of periodontopathogenic bacteria to killing by light from a low-power laser. Oral Microbiol Immunol 1992 (in press).

9. Venezio FR, DiVincenzo C, Sherman R et al. Bactericidal effects of photoradiation therapy with hematoporphyrin derivative. J Infect Dis 1985; 151: 166-169. 